\title{
Columnar Cell Variant Thyroid Gland Papillary Carcinoma
}

National Cancer Institute

\section{Source}

National Cancer Institute. Columnar Cell Variant Thyroid Gland Papillary Carcinoma. NCI

Thesaurus. Code C35830.

A morphologic variant of papillary carcinoma of the thyroid gland characterized by the presence of pseudostratified malignant follicular cells. 